\title{
PERINATAL OUTCOME OF TWIN PREGNANCIES DELIVERED IN A TEACHING HOSPITAL
}

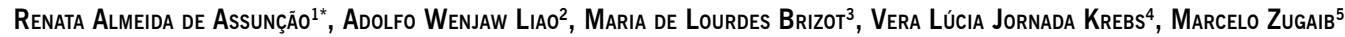

Study conducted at the Clínica Obstétrica do Hospital das Clinicas da Faculdade de Medicina da Universidade de São Paulo, São Paulo, SP

*Correspondência:

Rua Aimberê, 320 - Perdizes

CEP: 05018010

São Paulo - SP

\begin{abstract}
SUMMARY
OвJEctive. This study aimed to evaluate the perinatal outcome of twin pregnancies delivered in a tertiary teaching hospital according to chorionicity.

Methods. A retrospective study involving 289 twin pregnancies delivered from January 2003 to December 2006 was carried out. Maternal and perinatal data were obtained from hospital charts and delivery logs. Chorionicity was determined by ultrasonography or histopathological study.

Results. Incidence of twin gestations was 3.4\% and $96.4 \%$ were spontaneously conceived. $60.5 \%$ were dichorionic (DC), $30.8 \%$ of monochorionic diamniotic (MCDA), $6.6 \%$ monochorionic monoamniotic (MCMA) and for $2.1 \%$ chorionicity was unknown. The mean gestation age at delivery was respectively 35.4, 33.6, 32.9 for DC, MCDA and MCMA. The mean birth weight was 2.171, 1.832 and $1.760 \mathrm{~g}$ respectively for $\mathrm{DC}, \mathrm{MC}$ and MCMA. The proportion of fetuses delivered with less than 34 weeks in DC was of $21.7 \%$, while in MCDA it was of $39.3 \%$ and in MCMA of $42.1 \%$. Birth weight below the $10^{\text {th }}$ centile occurred in $15.7 \%$ for DC, $22.5 \%$ for MCDA and $26.3 \%$ in MCMA. Congenital anomalies were observed in $21.3 \%$ in monochorionic and in $7.4 \%$ in the dichorionic. Lenght of hospital stay was shorter for DC when compared to MCDA and MCMA twins (13.1, 17.3 and 23.3 days, respectively). The proportion of twin pregnancies with both babies discharged alive were $85.7 \%$ in DC and $61.1 \%$ in MC.

ConcLusion. The rate of preterm deliveries and low birth weight is higher in monochorionic pregnancies when compared to dichorionic twins. However, when adjusted for complications such as fetal abnormalities and twin-twin transfusion syndrome, double survival rates were similar in the two groups.
\end{abstract}

KEY wORDS: Perinatal mortality. Patient discharge. Twins. Premature birth. Pregnancy complications. Congenital abnormalities.

\section{INTRODUCTION}

The incidence of multiple pregnancies has shown a significant increase over the last decades due to postponement of maternity on the part of women and the dissemination of assisted reproduction techniques. In the United States, incidence of these pregnancies has increased by 59\% between 1980 and 1999, with twin pregnancies accounting for about $94 \%$ of all multiple pregnancies ${ }^{1}$.

Although twins occur in approximately one of 80 pregnancies, corresponding to $2.6 \%$ of all newborns, they account for $12.2 \%$ of preterm births and $15.4 \%$ of neonatal deaths ${ }^{2,3}$. The main causes of adverse neonatal outcomes in multiple pregnancies are related to prematurity, fetal growth restriction and low birth weight ${ }^{4}$. In addition, these pregnancies are prone to complications inherent to twinning, such as acardiac fetus, conjoined twins and twin-twin transfusion syndrome. In addition, the risk of congenital anomalies is about 1.7 times higher than among singleton pregnancies and is more significant in monozygotic pregnancies ${ }^{4,5}$.

Preterm birth is observed in approximately $54 \%$ of all twin pregnancies, half of these births have a iatrogenic origin and are related to maternal or fetal complication while the other half consists of cases of spontaneous premature labor or premature membrane rupture ${ }^{3}$. The average birth weight is $2367 \mathrm{~g}$ and about $52 \%$ of the newborns weigh less than $2500 \mathrm{~g}$. The risk of growth restriction is three times higher than in singleton pregnancies ${ }^{6,7}$.

All of these factors explain the high perinatal mortality observed in multiple pregnancies which is five to six times higher when compared to singleton pregnancies ${ }^{1}$. When analyzed

1. Médica do Hospital das Clínicas da Universidade de São Paulo, São Paulo, SP

2. Médico assistente da Clinica Obstétrica do Hospital das Clínicas da Universidade de São Paulo, São Paulo, SP

3. Médica assistente da Clinica Obstétrica do Hospital das Clínicas da Universidade de São Paulo, São Paulo, SP

4. Médica assistente responsável pelo setor de neonatologista do berçário anexo $10^{\circ}$ andar do Hospital das Clínicas, Faculdade de Medicina, Universidade de São Paulo, São Paulo, SP

5. Professor Titular da Clínica Obstétrica do Hospital das Clinicas da Faculdade de Medicina da Universidade de São Paulo, São Paulo, SP 
according to chorionicity, monochorionic pregnancies present a two to three times higher risk than dichorionic pregnancies ${ }^{8,9}$.

The objective of this study was to describe the perinatal outcome of twin pregnancies delivered at a tertiary teaching hospital according to chorionicity.

\section{Methods}

A retrospective analysis of twin pregnancies delivered at a gestational age of more than 20 weeks, at the Obstetrics Department of Sao Paulo University School of Medicine, between January 2003 and December 2006, was conducted, The cases were identified through the Institution birth registry and detailed information was obtained by analysis of hospital records. However, not all cases had their antenatal care in our Hospital. The following data were recorded for each case: maternal age, parity, gestational age at birth, route of delivery, birth weight, gender, and Apgar scores.

Chorionicity was determined by ultrasound examination in the antenatal or postnatal period by anatomopathological analysis and was classified as: dichorionic (DC), monochorionic diamniotic (MCDA), monochorionic monoamniotic (MCMA), or unknown. This Institution has a multiple pregnancies specialized unit and follows a management protocol that includes resolution of dichorionic twin pregnancies at 38 weeks of gestation, monochorionic diamniotic pregnancies at 36 weeks, and monochorionic monoamniotic pregnancies at 34 weeks.

Newborns weighing less than 2500 g were classified as low birth weight and those weighing less than $1500 \mathrm{~g}$ as very low birth weight. Birth weight was also classified based on the $10^{\text {th }}$ percentile for the respective gestational age according to the growth curve for twins ${ }^{10}$. A 5-minute Apgar score less than 7 was defined as a criterion of immediate neonatal morbidity. Congenital malformations were diagnosed by ultrasound examination during the antenatal period or by clinical examination of the neonate. Infants were followed up until hospital discharge and outcomes were classified as intrauterine death, neonatal death, live birth or unknown. Length of hospital stay comprised the period between the date of birth and the day of discharge.

Variables studied are reported as the mean, range, standard deviation (SD) and relative frequency. Proportions were compared between the dichorionic and monochorionic groups using the nonparametric Mann-Whitney test and chi-square test. $P$ values of $<0.05$ were considered to indicate statistically significant differences.

\section{Results}

During the study period, a total of 303 twin deliveries with a gestational age of more than 20 weeks took place in our Department with an incidence of twin deliveries of $3.4 \%$. Fourteen $(4.6 \%)$ cases were excluded due to incomplete information in the records.

Mean maternal age was 29.1 years (SD: 6.8 , range: 15 to $47)$ and the mean parity was 1.3 (SD: 1.5 , range: 0 to 9 ), with $39.4 \%$ of the pregnant women were nulliparous.

Eleven (3.8\%) pregnancies were conceived by assisted reproduction and the remaining by spontaneous conception. With respect to chorionicity, $175(60.5 \%)$ pregnancies were dichorionic, 89 (30.8\%) were MCDA, 19 (6.6\%) were MCMA, and chorionicity was unknown in $6(2.1 \%)$ cases.
The most frequent route of delivery was cesarean section (84.8\%), followed by vaginal delivery $(12.8 \%)$ and combined vaginal-abdominal delivery (2.4\%). The mean gestational age at delivery was 34.6 weeks (SD: 3.9 , range: 21.3 to 40.3). Spontaneous delivery was observed in 144 (49.8\%) cases, including 39 (27.1\%) after premature rupture of membrane and 105 (72.9\%) after spontaneous onset of labor. In the remaining cases $(n=145)$, resolution was indicated due to maternal-fetal complications ( $\mathrm{n}=$ $62,42.8 \%$ ) or based on our protocol ( $n=83,57.2 \%$ ).

Three of the 578 conceptuses were acardiac and 10 were conjoined twins. The mean birth weight of the newborns was 2031 g (SD: 693, range: 80 to 3530). Table 1 summarizes the newborns characteristics according to chorionicity.

There were 38 (6.6\%) intrauterine deaths (nine dichorionic, 26 monochorionic and three unknown). Death of both fetuses was observed in 10 pregnancies. Frequency of live births in the study group was $93.4 \%$ (540 newborns). Among these newborn, $62(11.5 \%)$ died during hospital stay. The frequency of live births was higher in dichorionic pregnancies $(97.4 \%)$ than in monochorionic pregnancies (88.0\%). Table 2 shows the frequency of perinatal outcomes according to chorionicity. Perinatal outcome according to gestational age at delivery is shown in Figure 1.

In dichorionic pregnancies, fetal gender was discordant in 72 (41.1\%) cases and concordant in 103 (58.9\%), with 52 twins being female and 51 male. In monochorionic pregnancies, there were 59 $(54.6 \%)$ female twin pairs and $49(45.4 \%)$ male twin pairs.

Fetal anomalies were observed in $37(12.8 \%)$ pregnancies, affecting 48 infants. Mean gestational age at delivery of these pregnancies was 33.4 weeks (SD: 4.6) and mean birth weight of the affected fetuses was $1596 \pm 759 \mathrm{~g}$. With respect to chorionicity, 13 (35.1\%) pregnancies were dichorionic, 15 (40.5\%) were MCDA, 8 (21.6\%) were MCMA and chorionicity was unknown in one case (2.8\%). In 11 (29.7\%) pregnancies, both fetuses had some congenital anomaly ( 1 dichorionic, 9 monochorionic and 1 with unknown chorionicity). In the 18 pregnancies in which only one fetus was affected, the healthy twin survived when delivery occurred after 30 weeks of gestation.

Among the anomalies observed, eight were complications specific to monochorionic pregnancies: acardiac $(n=3)$ and conjoined twins $(n=5)$. In the other cases, central nervous system $(n=8)$ and cardiac alterations $(n=7)$ were the main findings. Eight fetuses presented multiple malformations.

\footnotetext{
Figure 1 - Perinatal outcome of 289 twin pregnancies according to gestational age at delivery. Blue: Intrauterine death; red: neonatal death; green: alive.
}

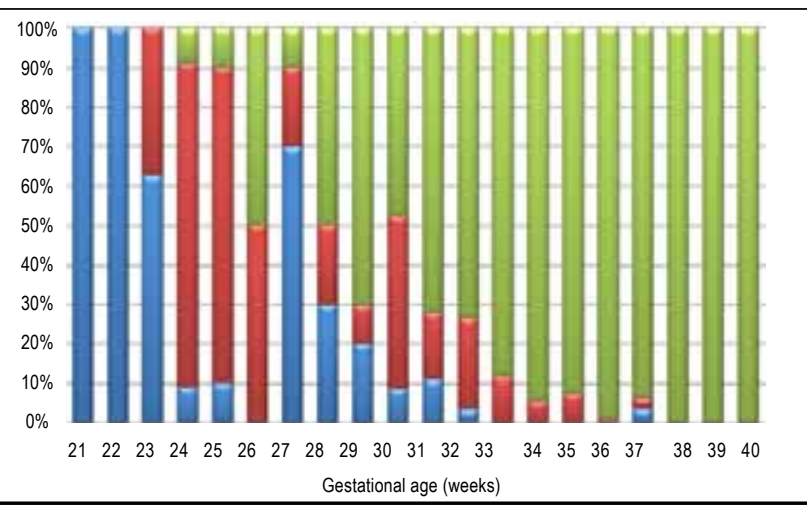


Table 1 - Perinatal outcome in $\mathbf{5 7 8}$ fetuses of twin pregnancies according to chorionicity

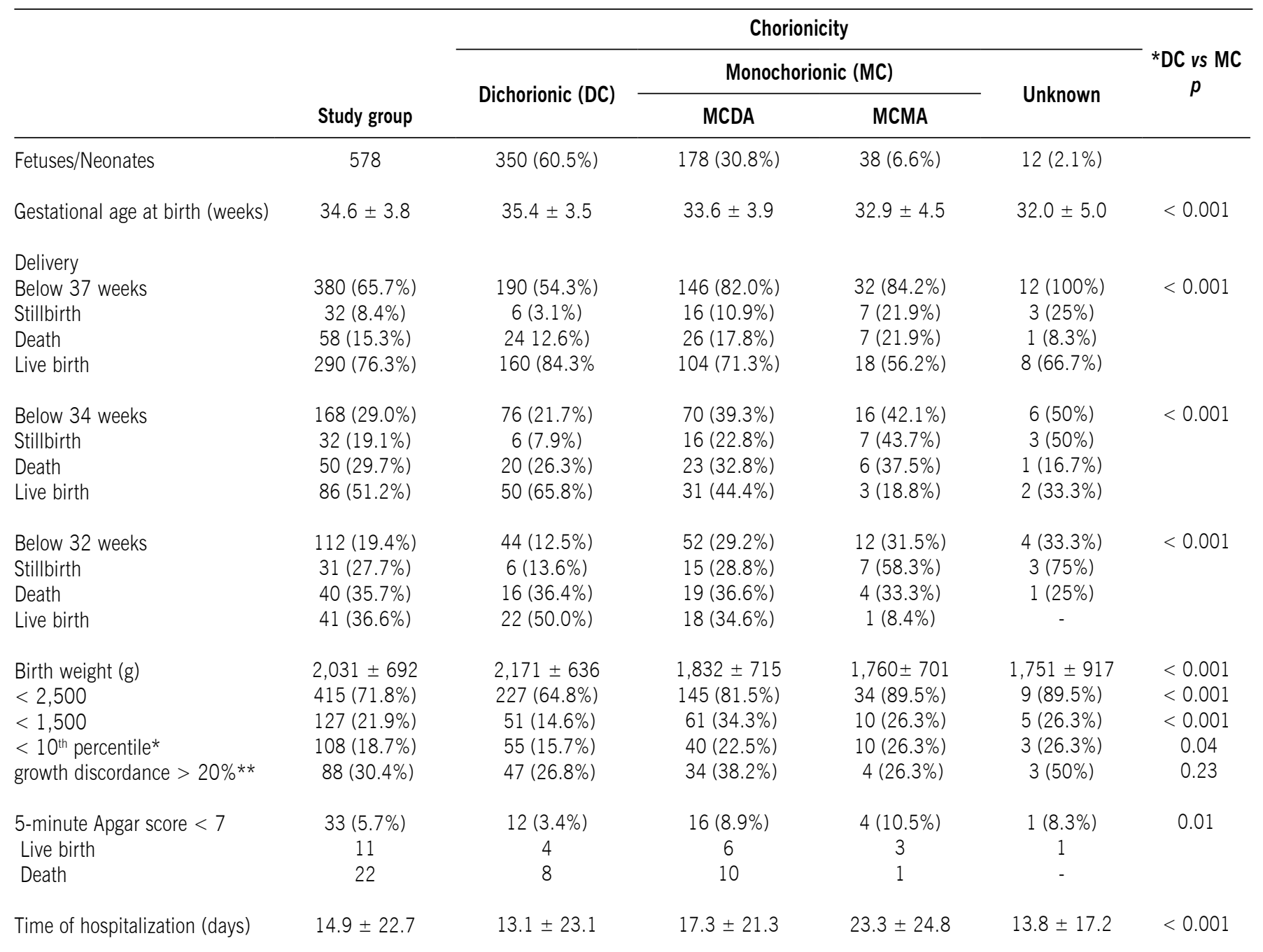

IUD: intrauterine death; NND:neonatal death; DC: dichorionic; MCDA: monochorionic diamniotic; MCMA: monochorionic monoamniotic; GA: gestational age. * Dichorionic vs monochorionic: $\mathrm{p}<0.001$ for the three comparisons. ${ }^{*}$ Growth curve for twins according to Alexander et al. (1998). *** Ratio of the difference between the birth weight of both newborns divided by weight of the larger twin

Table 2 - Survival rates in 289 twin pregnancies

\begin{tabular}{|c|c|c|c|c|}
\hline & $N$ & Both twins alive & At least one twin alive & None alive \\
\hline Dichorionic & 175 & $150(85.7 \%)$ & $167(95.4 \%)$ & $8(4.6 \%)$ \\
\hline Uncomplicated dichorionic & 161 & $147(91.3 \%)$ & $154(95.6 \%)$ & $7(4.4 \%)$ \\
\hline Monochorionic & 108 & $66(61.1 \%)$ & $87(80.5 \%)$ & $21(19.4 \%)$ \\
\hline Uncomplicated MC diamniotic & 58 & $48(82.7 \%)$ & $55(94.8 \%)$ & $10(17.3 \%)$ \\
\hline MC monoamniotic & 19 & $9(47.4 \%)$ & $12(63.1 \%)$ & $7(36.8 \%)$ \\
\hline Uncomplicated MC monoamniotic & 11 & $8(72.7 \%)$ & $8(72.7 \%)$ & $3(27.3 \%)$ \\
\hline
\end{tabular}

MC: monochorionic. 


\section{Discussion}

The high incidence of twin deliveries observed in our study is related to the fact that we are a tertiary teaching hospital focusing on care of high-complexity patients, which also explains the high frequency of monochorionic pregnancies and their complications. The incidence of twin deliveries was $3.4 \%$. According to DATASUS (health information database of the Brazilian Ministry of Health), the incidence of twin pregnancies in the State of São Paulo has increased from $1.8 \%$ to $2.1 \%$ of all live births between 2000 and $2005^{11}$.

About $95 \%$ of cases resulted from spontaneous conception. This finding is in contrast to other studies where the frequency of assisted reproduction techniques conceived pregnancies reaches $50 \%{ }^{12}$. This difference is explained by the profile of patients at our Hospital who are from a social stratum that usually has no access to these treatments.

In this study, the mean gestational age at delivery was 34.4 weeks, with $66.2 \%$ of deliveries before 37 weeks. The mean age at delivery of twin pregnancies reported in population studies is 35.6 weeks ${ }^{6}$. This difference might be explained by the high frequency of pregnancies with complications referred to our Hospital. In a previous study in which cases with diagnosis of fetal malformations and twin-twin transfusion syndrome were excluded, we observed a mean gestational age at birth of 35.6 weeks $^{13}$.

According to chorionicity, the mean gestational age at delivery was lower in monochorionic pregnancies compared to dichorionic. The proportion of twins born before 32 weeks (extreme preterm) was 2.5 times higher among monochorionic than dichorionic (30\% versus $13 \%$ ) and was statistically significant. Gestational age is even lower in the presence of complications such as fetal malformations or twin-twin transfusion syndrome, whose association with prematurity markedly increases perinatal mortality.

The birth weight of newborn twins is known to be lower than that of singleton newborns, with an 8.3 times higher risk of birth weight below $2500 \mathrm{~g}$ and a ten times higher risk of birth weight of less than $1500 \mathrm{~g}^{14}$. The mean birth weight reported in population studies is about $2300 \mathrm{~g}^{7}$. According to DATASUS, $57.8 \%$ of newborn twins in Brazil in 2005 weighed less than $2500 \mathrm{~g}$ $(7.0 \% \text { in singleton pregnancies })^{11}$. Fujita et al. ${ }^{15,16}$ demonstrated that the growth curve of twin fetuses deviates from the curve of singleton fetuses after 28 weeks of gestation. In this study which included fetuses with malformations, the mean birth weight was $2026 \mathrm{~g}$ and $32.4 \%$ presented a weight below the 10th percentile. In a previous study from our Hospital in which cases of fetal malformations and those complicated by twin-twin transfusion syndrome were excluded, the mean birth weight was $2198 \mathrm{~g}^{13}$.

Classification according to chorionicity showed a mean birth weight of $2165 \mathrm{~g}$ for dichorionic pregnancies and of $1827 \mathrm{~g}$ for monochorionic pregnancies. Therefore, $2500 \mathrm{~g}$ as a parameter for the definition of low birth weight does not seem to be adequate for twin pregnancies. When the $10^{\text {th }}$ percentile of the Alexander standard growth curve for twins was used, a birth weight below the $10^{\text {th }}$ percentile was observed in $4.9 \%$ of newborn of dichorionic pregnancies, whereas this percentage was $23.1 \%$ for monochorionic pregnancies, similar to that previously reported by Sebire et al. ${ }^{17}$.

In pregnancies with fetal malformations, frequency of intrauterine death of the affected twin was high, whereas the same was not observed for the healthy co-twin. In fact, when delivery occurred after 30 weeks of gestation all normal fetuses survived, irrespectively of chorionicity. In contrast, when delivery occurred before 28 weeks all healthy twins died, a finding probably related to the complications of extreme prematurity. In agreement with a study previously published by this same group, the present results demonstrate that fetal malformations increase the risk of preterm delivery compared to twin pregnancies without fetal anomalies. This associated prematurity is responsible for the increased perinatal mortality observed ${ }^{5}$.

From the findings of this study, it seems that overall uncomplicated monochorionic and dichorionic twins have similar survival rates. However we need to consider that the present data did not include cases followed during all the antenatal period and therefore we may have missed the uncomplicated monochorionic cases that can suddenly die in utero without explanation, as reported in literature. On the other hand we have a protocol to deliver monochorionic twins earlier to avoid the risk of intrauterine death.

In view of the increasing incidence of twin pregnancies observed over the past few years, obstetricians must be aware of the risks related to this type of pregnancy. Twin pregnancy increases the risks of both maternal and fetal complications. Chorionicity is fundamental for fetal management during these pregnancies and can be determined by ultrasound examination performed by trained physicians early in the first trimester. In addition, periodic ultrasound follow-up enables prediction with good accuracy of the pregnancies that are at an increased risk for fetal growth restriction and discordant growth ${ }^{18}$. Thus, specific and specialized follow-up might be necessary depending upon the type of twin pregnancy and presence of eventual maternal or fetal complications.

Within the context of public health, the formation of groups specialized in the care of twin pregnancies has led to a reduction in maternal-fetal morbidity and mortality, since they can detect at an early date, complications frequently associated with these pregnancies. Finally, they are more experienced in the management of these complications ${ }^{19}$, thus optimizing neonatal outcome.

\section{Conclusion}

Mean gestacional age at delivery, birth weight, fetal growth restriction and congenital anomalies are more common in monochorionic than in dichorionic pregnancies. Survival rates for two live children are similar for dichorionic and monochorionic gestations without complications. However, if malformations and the twin-twin transfusion syndrome are present, this chance is reduced to $60 \%$ and worst for monochorionic monoamniotic gestations.

\section{Conflict of interest: none}

\section{Resumo}

Resultado perinatal de gestações gemelares com parto em HOSPITAL UNIVERSITÁRIO

OBJEtIvo. Avaliar o resultado perinatal nas gestações gemelares com partos em hospital universitário segundo a corionicidade.

MÉTODos. Estudo retrospectivo de 289 gestações gemelares com partos no Hospital das Clínicas da Faculdade de Medicina da Universidade de São Paulo, no período de janeiro de 2003 a dezembro de 2006. Os dados maternos e fetais foram obtidos 
através dos livros de parto e dos prontuários da instituição. A corionicidade foi determinada pela ultrassonografia ou pelo exame anatomopatológico.

Resultados. A incidência de gestação gemelar foi de 3,4\% sendo 96,6\% naturalmente concebidas. Dos 578 conceptos, 60,5\% eram de gestações dicoriônicas (DC), 30,8\% monocoriônicas diamnióticas (MCDA), 6,6\% monocoriônicas monoamnióticas (MCMA) e em 2,1\% a corionicidade era desconhecida. A idade gestacional (IG) média do parto foi de 34,6 semanas $(D P=3,9)$ e o peso médio ao nascimento foi de 2.031g $(D P=693)$. Nas gestações $D C$ a IG média foi de 35,4 semanas $(D P=3,5) ; M C D A$ foi de 33, $6(D P=3,9)$ e nas MCMA foi de 32, $9(D P=4,5)$, sendo estatisticamente significativo. O peso médio ao nascer foi 2.171g, $1.832 \mathrm{~g}$ e $1.760 \mathrm{~g}$, respectivamente, para as gestações $D C, M C D C$ e MCMA. A proporção de fetos com IG no parto abaixo de 34 semanas nas gestações DC foi de $21,7 \%$ enquanto nas MCDA foi de $39,3 \%$ e nas MCMA foi de 42, 1\%. A frequência de fetos abaixo do percentil 10 para gêmeos foi 15,7\% DC, 22,5\% MCDA e 26,3\% nas MCMA. As malformações fetais foram observadas em $21,3 \%$ das monocoriônicas e em $7,4 \%$ nas dicoriônicas. 0 período de hospitalização foi menor nas dicorionicas quando comparadas com as MCDA e MCMA (17,1; 17,3 e 23,3 dias, respectivamente). A porcentagem de alta hospitalar de ambos os recém-nascidos com vida foi maior nas gestações DC (85, 7\%) do que nas gestações MC (61,1\%), porém quando excluídas as complicações (malformações fetais e a síndrome da transfusão feto-fetal) a sobrevida de ambos os recém-nascidos nas MC foi de $80 \%$.

Conclusão. A idade gestacional do parto, o peso ao nascimento e a restrição do crescimento fetal são significativamente menores nas gestações monocoriônicas. A chance de o casal levar para casa dois filhos vivos é semelhante nas gestações dicoriônicas e nas monocoriônicas na ausência de complicações. Porém, na presença de malformações e da síndrome da transfusão feto-fetal, esta chance se reduz para 60\%, sendo pior nas monocoriônica monoamnóticas. [Rev Assoc Med Bras 2010; 56(4): 447-51]

UnIteRmos: Gêmeos. Mortalidade perinatal. Alta do paciente. Nascimento prematuro. Complicações na gravidez. Anormalidades congênitas.

\section{RefERENCES}

1. Russell RB, Petrini JR, Damus K, Mattison DR, Schwarz RH. The changing epidemiology of multiple births in the United States. Obstet Gynecol. 2003;101(1):129-35.

2. Ghai V, Vidyasagar D. Morbidity and mortality factors in twins. An epidemiologic approach. Clin Perinatol. 1988;15(1):123-40.
3. Gardner MO, Goldenberg RL, Cliver SP, Tucker JM, Nelson KG, Copper RL. The origin and outcome of preterm twin pregnancies. Obstet Gynecol. $1995 ; 85(4): 553-7$

4. Glinianaia SV, Rankin J, Renwick M. Time trends in twin perinatal mortality in northern England, 1982-94. Northern Region Perinatal Mortality Survey Steering Group. Twin Res. 1998;1(4):189-95

5. Brizot M, Fujita M, Reis N, Banduki J, Schultz R, Miyadahira S, et al. Malformações fetais em gestação múltipla. Rev Bras Ginecol Obstet. 2000;22(8):511-7

6. Alexander GR, Salihu HM. Perinatal outcomes of singleton and multiple births in the United States, 1995-98. In: Blickstein I, Keith LG, editors. Multiple Pregnancy: epidemiology, gestation \& perinatal outcome. 2nd ed. Andover: Thompson Publishing Services; 2005. p.3-10.

7. Umstad MP, Lancaster PAL. Multiple births in Australia. In: Blickstein I, Keith LG, editors. Multiple pregnancy: epidemiology, gestation \& perinatal outcome. 2nd ed. Andover: Thomson Publishing Services; 2005. p.26-32.

8. Hack KE, Derks JB, Elias SG, Franx A, Roos EJ, Voerman SK, et al. Increased perinatal mortality and morbidity in monochorionic versus dichorionic twin pregnancies: clinical implications of a large Dutch cohort study. $\mathrm{Br} \mathrm{J}$ Obstet Gynecol. 2008;115(1):58-67.

9. Loos R, Derom C, Vlietinck R, Derom R. The East Flanders Prospective Twin Survey (Belgium): a population-based register. Twin Res. 1998;1(4):167-75.

10. Alexander GR, Kogan M, Martin J, Papiernik E. What are the fetal growth patterns of singletons, twins, and triplets in the United States? Clin Obstet Gynecol. 1998;41(1):114-25.

11. DATASUS. Informações em Saúde. Estatisticas Vitais. Nascidos vivos estado de São Paulo. Disponível em: http://tabnet.datasus.gov.br/cgi/deftohtm. exe?sinasc/cnv/nvsp.def.

12. Derom C, Derom R. The east flanders prospective twin survey. In: Blickstein I, Keith LG, editors. Multiple pregnancy: epidemiology, gestation \& perinatal outcome. 2nd ed. Andover: Thompson Publishing Services, 2005. p.39-46.

13. Machado RCA. Gestações gemelares com pesos discordantes: estudo da predição ultra-sonográfica e dos resultados neonatais [dissertação]. São Paulo: Faculdade de Medicina, Universidade de São Paulo; 2006.

14. Luke B, Keith LG. The contribution of singletons, twins and triplets to low birth weight, infant mortality and handicap in the United States. J Reprod Med. 1992;37(8):661-6.

15. Fujita MM. Avaliação ultra-sonográfica do crescimento fetal em gestações gemelares [tese]. São Paulo: Faculdade de Medicina, Universidade de São Paulo; 1998.

16. Hadlock FP, Harrist RB, Martinez-Poyer J. In utero analysis of fetal growth: a sonographic weight standard. Radiology. 1991;181(1):129-33.

17. Sebire NJ, Snijders RJ, Hughes K, Sepulveda W, Nicolaides KH. The hidden mortality of monochorionic twin pregnancies. Br J Obstet Gynaecol. 1997;104(10):1203-7.

18. Machado RC, Brizot ML, Liao AW, Cabar FR, Zugaib M. Prenatal sonographic prediction of twin growth discordance. Twin Res Hum Genet. 2007;10(1):198-201.

19. Newman RB. Routine antepartum care of twin. In: Blickstein I, Keith LG, editors. Multiple pregnancy: epidemiology, gestation and perinatal outcome. 2nd ed. Andover: Thompson Publishing Services ; 2005. p.405-19. 